\title{
Effect of Microwave-Assisted Extraction on Polyphenols Recovery from Tomato Peel Waste
}

\section{Marina Tranfić Bakić, Sandra Pedisić, Zoran Zorić, Verica Dragović-Uzelac and Antonela Ninčević Grassino*}

\author{
Faculty of Food Technology and Biotechnology, University of Zagreb, Pierottijeva 6, 10000 Zagreb, Croatia \\ * Corresponding author: E-mail: aninc@pbf.hr \\ Phone: +38514605062 Fax: +38514836083
}

Received: 11-22-2018

\begin{abstract}
This study describes the application of microwave-assisted extraction (MAE) as an innovative technique for isolation of polyphenols from tomato peel waste. Effects of solvents, temperatures $\left(25,55\right.$ and $\left.90{ }^{\circ} \mathrm{C}\right)$ and times $(5$ and 10 min) were evaluated with regard to total phenols (TP), total flavonoids (TF) and phenolic compound contents. Tomato peel extracts contain high amounts of kaemferol-3-O-rutinoside ( 8.5 to $142.5 \mathrm{mg} \mathrm{kg}^{-1}$ ), $p$-coumaric acid (3 to $\left.111.5 \mathrm{mg} \mathrm{kg}^{-1}\right)$ and chlorogenic acid derivative ( 10.5 to $\left.109 \mathrm{mg} \mathrm{kg}^{-1}\right)$. Results revealed that extraction time has no significant $(p>0.05)$ influence on TP, TF and phenolic compounds recovery (exception is cis- $p$-coumaric acid hexoside). On the other hand, the influence of temperature and chosen solvent on polyphenols yield is significant.

Considering interest of consumers to intake natural compounds exhibiting antioxidant properties, this work suggests that tomato peel waste can be used as one of sustainable resources for polyphenols production by MAE.
\end{abstract}

Keywords: Tomato peel waste; microwaves-assisted extraction; polyphenols; HPLC-DAD

\section{Introduction}

Tomato edible fruit of Solanum lycopersicum, which belongs to the Solanaceae family, is the second most produced and consumed vegetable in the world, either fresh or processed in the form of canned tomatoes, sauce, juice, ketchup and soup. Industrial processing of tomato generates significant amounts of waste, consisting mainly of tomato peels and seeds, but also leaves and stems. The management of tomato by-products is considered an important problem faced by tomato processing companies, due to its disposal to the environment. Usually, they are partially reused by composting or drying for animal feeding. However, modern eco-compatible technologies offer more efficient strategies to recycle these by-products and reuse them as a sustainable source of different nutrients and highly biologically active compounds, such as amino acids, fatty acids, minerals and carotenoids. ${ }^{1-3}$ Apart from carotenoids, i.e. lycopene and $\beta$-carotene found in major amounts, tomato by-products are also rich in phenolic compounds. ${ }^{2,4-6}$

Variations in chemistry of phenolic compounds in fruits, vegetables and agri-industrial wastes are related to different proportions of simple and complex phenols, such as benzoic and cinnamic acids, coumarins, tannins, lignins, lignans and flavonoids. ${ }^{7}$ These diverse forms of phenolic compounds show variable responses to different extraction conditions. Furthermore, the optimum recovery of phenolics differs from one substrate to the other and depends on the type of fruit, vegetable and their by-products.

In order to maximize the recovery of polyphenols from tomato waste, different conventional $^{8-15}$ and non-conventional (sonication or ultrasonic bath) ${ }^{16,17}$ extraction techniques, as well as operation conditions (time, temperature, polarity of solvent and addition of hydrochloric acid or sodium hydroxide to organic solvents) were employed. Several researches ${ }^{4,5,18,19}$ have reported that conventional methods, such as Soxhlet extraction and refluxing, had significant disadvantages like long extraction times, evaporation of the huge amounts of solvents, and thermal decomposition of thermo-labile compounds. To overcome these limitations, new and promising extraction methods, such as ultrasound-assisted extraction, enzyme-assisted extraction, and pressurized liquid extraction, were recently introduced for polyphenols isolation. ${ }^{4,5,18,19}$ Another one of the innovative and advanced techniques is microwave-assisted extraction (MAE), which provides greater extraction efficiency in shorter time, at lower temperature and with smaller amount of 
solvent. ${ }^{20,21}$ In this method, the separation of solutes from sample matrix is based on the conversion of microwave energy to heat, by ionic conduction and dipole rotation. ${ }^{22}$

The structure and polarity of target compound, environmental safety, human toxicity, and financial feasibility are main factors in the choice of solvent. Water, methanol, ethanol, acetone, hexane and their combinations, are commonly used for polyphenols extractions from tomato waste. ${ }^{8-10,12-17,23}$ The addition of hydrochloric acid or sodium hydroxide to water or water/organic solvent mixtures was also reported to enhance the extraction of phenolic compounds. ${ }^{10,17}$

Considering health benefits of phenolic compounds and growing interest of consumers to intake natural compounds exhibiting antioxidant properties, this work presents re-utilization of tomato peel waste from canning factory as an additional, low-cost, sustainable resources for the production of polyphenols.

Apart from direct addition of dried tomato waste to various food products, such as meat, bread and cookies, ${ }^{24-26}$ the carotenoids, mostly lycopene, isolated from tomato by-products could be also utilized as a food colorants and functional ingredients. ${ }^{6}$ In that context and from the agro-industrial point of view, the phenolic compounds extracted in this work could be further used for enrichment of different foodstuffs.

The fact that only a few papers ${ }^{16,17,27}$ reported extraction of polyphenols from tomato wastes using non-conventional extraction method inspired us to focus our attention on utilization of MAE as a novel, not yet explored method for polyphenols isolation from tomato peel. Hence, this paper describes the effect of solvent type, acidity, temperature, and time on extraction of polyphenols using MAE as simple, quick and environmentally friendly technique, and defines the optimal parameters for MAE that yield the highest possible amounts of polyphenols with minimum expenditure of extraction resources.

\section{Materials and Methods}

\section{1. Materials}

All the reagents, standards and solvents were of analytical grade. Folin-Ciocolateu reagent and all standards (gallic acid, rutin, caffeic acid, chlorogenic acid, $p$-coumaric acid, quercetin and kaempferol) were purchased from Sigma Aldrich (Steinheim, Germany). Ethanol, methanol, hydrochloric acid, sodium carbonate, sodium nitrite and aluminium chloride hexahydrate were obtained from Kefo (Zagreb, Croatia). Formic acid and acetonitrile (HPLC grade) was purchased from Prolabo (Lutterworth, UK). Deionised water used for the preparation of reagents, standards and solvents was obtained with Millipore-MilliQ apparatus.

Tomato peel waste was purchased from the manufacturing unit (after processing of fresh tomato) of Benin-
Table 1. Microwave-assisted extraction (MAE) of polyphenols from tomato peel waste using water, $1 \% \mathrm{HCl}, 50$ and $70 \%$ methanol $(\mathrm{MeOH})$ with and without addition of $1 \% \mathrm{HCl}$, and 50 and $70 \%$ ethanol (EtOH), at temperature of 25,55 and $90{ }^{\circ} \mathrm{C}$, and time of 5 and $10 \mathrm{~min}$

\begin{tabular}{|c|c|c|c|c|c|}
\hline Run & Sample & Temperature/ & $\mathrm{e} /{ }^{\circ} \mathrm{C}$ Solvent & $\mathrm{HCl}$ & Time/min \\
\hline 1 & 1A & 25 & \multirow{6}{*}{$\mathrm{H}_{2} \mathrm{O}$} & \multirow{6}{*}{ / } & \\
\hline 2 & $1 \mathrm{~A}$ & 55 & & & 5 \\
\hline 3 & $1 \mathrm{~A}$ & 90 & & & \\
\hline 4 & $1 \mathrm{~B}$ & 25 & & & \\
\hline 5 & 1B & 55 & & & 10 \\
\hline 6 & 1B & 90 & & & \\
\hline 7 & $2 \mathrm{~A}$ & 25 & \multirow{6}{*}{$\mathrm{H}_{2} \mathrm{O}$} & \multirow{6}{*}{$1 \%(v / v)$} & \\
\hline 8 & $2 \mathrm{~A}$ & 55 & & & 5 \\
\hline 9 & $2 \mathrm{~A}$ & 90 & & & \\
\hline 10 & $2 B$ & 25 & & & \\
\hline 11 & $2 B$ & 55 & & & 10 \\
\hline 12 & $2 B$ & 90 & & & \\
\hline 13 & $3 A$ & 25 & \multirow{6}{*}{$50 \%(v / v) \mathrm{MeOH}$} & & \\
\hline 14 & $3 A$ & 55 & & & 5 \\
\hline 15 & $3 \mathbf{A}$ & 90 & & $1 \%(\mathrm{v} / \mathrm{v})$ & \\
\hline 16 & $3 B$ & 25 & & & \\
\hline 17 & $3 B$ & 55 & & & 10 \\
\hline 18 & $3 B$ & 90 & & & \\
\hline 19 & $4 \mathrm{~A}$ & 25 & \multirow{6}{*}{$70 \%(v / v) \mathrm{MeOH}$} & & 5 \\
\hline 20 & $4 \mathrm{~A}$ & 55 & & & \\
\hline 21 & $4 \mathrm{~A}$ & 90 & & $1 \%(v / v$ & \\
\hline 22 & $4 B$ & 25 & & $11 \%(\mathrm{~V} / \mathrm{V})$ & \\
\hline 23 & $4 B$ & 55 & & & 10 \\
\hline 24 & $4 B$ & 90 & & & \\
\hline 25 & $5 \mathrm{~A}$ & 25 & \multirow{6}{*}{$50 \%(v / v) \mathrm{MeOH}$} & \multirow{6}{*}{1} & \\
\hline 26 & $5 \mathrm{~A}$ & 55 & & & 5 \\
\hline 27 & $5 \mathrm{~A}$ & 90 & & & \\
\hline 28 & $5 B$ & 25 & & & \\
\hline 29 & $5 B$ & 55 & & & 10 \\
\hline 30 & $5 B$ & 90 & & & \\
\hline 31 & $6 \mathrm{~A}$ & 25 & \multirow{6}{*}{$70 \%(v / v) \mathrm{MeOH}$} & \multirow{6}{*}{+1} & \\
\hline 32 & $6 \mathrm{~A}$ & 55 & & & 5 \\
\hline 33 & $6 A$ & 90 & & & \\
\hline 34 & $6 B$ & 25 & & & \\
\hline 35 & $6 B$ & 55 & & & 10 \\
\hline 36 & $6 B$ & 90 & & & \\
\hline 37 & $7 \mathrm{~A}$ & 25 & \multirow{6}{*}{$50 \%(v / v) \mathrm{EtOH}$} & \multirow{6}{*}{1} & \\
\hline 38 & $7 \mathrm{~A}$ & 55 & & & 5 \\
\hline 39 & $7 \mathrm{~A}$ & 90 & & & \\
\hline 40 & $7 B$ & 25 & & & \\
\hline 41 & $7 B$ & 55 & & & 10 \\
\hline 42 & $7 B$ & 90 & & & \\
\hline 43 & $8 \mathrm{~A}$ & 25 & \multirow{6}{*}{$70 \%(v / v) \mathrm{EtOH}$} & \multirow{6}{*}{1} & \\
\hline 44 & $8 \mathrm{~A}$ & 55 & & & 5 \\
\hline 45 & $8 \mathrm{~A}$ & 90 & & & \\
\hline 46 & $8 B$ & 25 & & & \\
\hline 47 & $8 B$ & 55 & & & 10 \\
\hline 48 & 8B & 90 & & & \\
\hline
\end{tabular}


casa S.r.l., canning industry located in the Agro Nocerina area of Campania (Angri, Italy). The tomato peel was dried, grounded and packed in polyethylene bags until analysis.

\section{2. Microwave-Assisted Extraction Procedure}

Microwave-assisted extractions (MAEs) were carried out in a Milestone START S Microwave Labstation for Synthesis (Bergamo, Italy), using water and water solution of $\mathrm{HCl}(1 \%, v / v)$, methanol (50 and $70 \%, v / v)$, with or without addition of $1 \% \mathrm{HCl}$ and ethanol (50 and 70\% v/v) (Table 1). The MAE parameters were times of 5 and 10 min, and temperatures of 25,55 and $90{ }^{\circ} \mathrm{C}$ (Table 1 ).

Tomato peel sample $(1.00 \mathrm{~g})$ was mixed with $50 \mathrm{~mL}$ of solvent in a round flask, placed in the MAE apparatus equipped with a condenser and subjected to microwave irradiation, at atmospheric pressure. The power of irradiation was varied from 0 to $500 \mathrm{~W}$ to maintain the set extraction temperature. After extraction, the mixture was left to cool down at room temperature and then filtered. The extracts were collected and stored at $-8{ }^{\circ} \mathrm{C}$ until further analyses.

\section{3. Total Phenols Content}

Total phenols (TP) content was determined using the Folin-Ciocalteu method, according to the procedure obtained by Spanos and Worlstad. ${ }^{28}$ The detailed procedure is given in the Supporting Information (SI). TP content is expressed as $\mathrm{g}$ of gallic acid equivalent (GAE) per $\mathrm{kg}$ of tomato peel sample. All the experiments were performed in triplicate and the presented results are the mean values.

\section{4. Total Flavonoids Content}

Total flavonoids (TF) content was determined using the aluminum chloride colorimetric assay developed by Zhishen, Mengcheng and Jianming. ${ }^{29}$ The detailed procedure is given in the SI. TF content is expressed as $g$ of rutin equivalent (RE) per kg of tomato peel sample. All the experiments were performed in triplicate and the results are reported as mean values.

\section{5. Phenolic Compounds Content}

HPLC analysis of individual phenolic compounds in the tomato peel extracts was performed by a liquid chromatograph (Agilent Technologies 1260 series) with a quaternary pump, equipped with a diode array detector (DAD). The HPLC system was controlled by OpenLAB ChemStation Software. Phenolic compounds were separated on a $250 \times 4.6 \mathrm{~mm}, 5 \mu \mathrm{m}$ film thickness Nucleosil 100-5C18 column (Sigma Aldrich). The column tempera- ture was $35^{\circ} \mathrm{C}$. The gradient elution conditions were previously described by Barros et al. ${ }^{30}$ Identification of phenolic compounds was carried out by comparing the retention time and spectral data with those of standards, i.e. caffeic acid, chlorogenic acid, $p$-coumaric acid, quercetin and kaempferol (Sigma Aldrich). The results are expressed in $\mathrm{mg}$ of phenolic compounds per $\mathrm{kg}$ of tomato peel.

\section{6. Experimental Procedure and Statistical Analysis}

The evaluation of under-utilized tomato peel waste as a potential source of polyphenols and MAE as an advanced technique for their extraction was performed in three steps. Firstly, TP and TF were quantified spectrophotometrically, screening the extraction parameters, i.e. solvent, time, temperature and addition of hydrochloric acid (Table 1), to determine which combination assures the highest amounts. Afterwards, selected phenolic compounds were identified and quantified by HPLC-DAD, and influence of extraction parameters on their yields was studied.

Finally, multivariate analyses of variance (MANOVA) were performed using Statistica 12 package (StatSoft) to compare the mean mass fraction values $(N=3)$ of TP, TF and individual phenolic compounds, depending on the used solvents, addition of hydrochloric acid, extraction time and temperature. Post-hoc Tukey HSD test provided additional insight by identifying the means that are significantly different from the other $(p<0.05)$.

\section{Results and Discussion}

\section{1. Influence of Experimental Conditions on Total Phenols and Flavonoids Recovery}

Content of total phenols (TP) and total flavonoids (TF) in tomato peel samples, acquired by MAE are presented in Table 2.

Generally, all samples contained high amounts of TP with variations due to different extraction time, temperature, and solvent. The average TP content was $53.12 \mathrm{~g} \mathrm{~kg}^{-1}$, and the lowest value was obtained for samples extracted at $25^{\circ} \mathrm{C}$, while higher values were found in samples extracted at 55 and $90^{\circ} \mathrm{C}$. Evidently, the temperature (Figure 1 and Figure S1, SI) had a significant influence on the extractions of phenols $\left(p=0.000125\right.$ for $25^{\circ} \mathrm{C}$ vs $90{ }^{\circ} \mathrm{C}$ and $p=$ 0.000770 for $55^{\circ} \mathrm{C}$ vs $90{ }^{\circ} \mathrm{C}$ ).

Regarding the TF content, the average amount was $50.36 \mathrm{~g} \mathrm{~kg}^{-1}$. Again, higher extraction temperatures yielded higher average contents of TF. Like for phenols, the increase of temperature also improved the solubility of flavonoids (Figure 1 and Figure S1, SI). A rise from 25 to 55 and $90{ }^{\circ} \mathrm{C}$ significantly $(p=0.000126$ and $p=0.000223)$ en- 
Table 2. Content of total phenols (TP) and total flavonoids (TF) obtained from tomato peel waste, extracted by MAE, at temperature of 25,55 and $90{ }^{\circ} \mathrm{C}$ for $5 \mathrm{~min}(\mathbf{1 - 8 A})$ and $10 \mathrm{~min}(\mathbf{1 - 8 B})$, using water (1A-B), $1 \% \mathrm{HCl}(\mathbf{2 A}-\mathbf{B}), 50$ and $70 \%$ methanol with (3A-B and 4A-B) and without (5A-B and $\mathbf{6 A - B})$ addition of $1 \% \mathrm{HCl}$, and 50 and $70 \%$ ethanol (7A-B and $\mathbf{8 A - B})$

\begin{tabular}{|c|c|c|c|c|c|c|}
\hline \multirow[t]{2}{*}{ Sample } & \multicolumn{3}{|c|}{$w(\mathrm{TP}) /\left(\mathrm{g} \mathrm{kg}^{-1}\right) \pm \mathrm{SD}^{*}$} & \multicolumn{3}{|c|}{$w(\mathrm{TF}) /\left(\mathrm{g} \mathrm{kg}^{-1}\right) \pm \mathrm{SD}^{*}$} \\
\hline & \multirow[t]{2}{*}{25} & \multirow{2}{*}{55} & \multicolumn{2}{|c|}{$90{ }^{T(\text { extraction }) /{ }^{\circ} \mathrm{C}} 25$} & \multirow[t]{2}{*}{55} & \multirow[t]{2}{*}{90} \\
\hline \multicolumn{3}{|c|}{$t=5 \mathrm{~min}$} & & & & \\
\hline $1 \mathrm{~A}$ & $54.01 \pm 0.06$ & $55.03 \pm 0.04$ & $54.50 \pm 0.12$ & $39.84 \pm 0.19$ & $57.05 \pm 0.17$ & $36.57 \pm 0.07$ \\
\hline $2 \mathrm{~A}$ & $57.18 \pm 0.11$ & $48.63 \pm 0.01$ & $59.86 \pm 0.09$ & $39.30 \pm 0.11$ & $36.08 \pm 0.08$ & $46.30 \pm 0.09$ \\
\hline $3 A$ & $57.98 \pm 0.06$ & $50.91 \pm 0.13$ & $57.81 \pm 0.03$ & $39.28 \pm 0.19$ & $34.46 \pm 0.15$ & $43.95 \pm 0.08$ \\
\hline $4 \mathrm{~A}$ & $35.08 \pm 0.17$ & $55.29 \pm 0.70$ & $63.57 \pm 0.19$ & $45.56 \pm 0.24$ & $36.92 \pm 0.13$ & $55.98 \pm 0.09$ \\
\hline $5 \mathrm{~A}$ & $40.82 \pm 0.12$ & $52.25 \pm 0.03$ & $61.65 \pm 0.06$ & $50.14 \pm 0.29$ & $46.77 \pm 0.16$ & $61.76 \pm 0.15$ \\
\hline $6 \mathrm{~A}$ & $32.55 \pm 0.16$ & $44.81 \pm 0.19$ & $62.69 \pm 0.09$ & $29.92 \pm 0.18$ & $49.60 \pm 0.08$ & $62.88 \pm 0.22$ \\
\hline $7 \mathrm{~A}$ & $44.32 \pm 0.05$ & $54.81 \pm 0.13$ & $63.36 \pm 0.02$ & $38.73 \pm 0.24$ & $51.45 \pm 0.33$ & $71.37 \pm 0.47$ \\
\hline $\mathbf{8 A}$ & $37.15 \pm 0.15$ & $46.66 \pm 0.29$ & $59.45 \pm 0.05$ & $46.87 \pm 0.25$ & $57.77 \pm 0.07$ & $107.47 \pm 0.05$ \\
\hline \multicolumn{7}{|c|}{$t=10 \mathrm{~min}$} \\
\hline 1B & $57.67 \pm 0.03$ & $51.07 \pm 0.12$ & $57.21 \pm 0.07$ & $41.20 \pm 0.15$ & $33.05 \pm 0.04$ & $47.30 \pm 0.04$ \\
\hline $2 B$ & $58.40 \pm 0.21$ & $55.32 \pm 0.56$ & $60.06 \pm 0.22$ & $39.97 \pm 0.30$ & $35.47 \pm 0.09$ & $43.28 \pm 0.09$ \\
\hline $3 B$ & $57.38 \pm 0.17$ & $53.39 \pm 0.73$ & $59.29 \pm 0.07$ & $42.30 \pm 0.10$ & $37.08 \pm 0.15$ & $54.18 \pm 0.04$ \\
\hline $4 B$ & $39.03 \pm 0.33$ & $59.36 \pm 0.17$ & $67.33 \pm 0.05$ & $51.80 \pm 0.32$ & $38.86 \pm 0.18$ & $60.32 \pm 0.32$ \\
\hline $5 B$ & $36.49 \pm 0.06$ & $55.44 \pm 0.07$ & $78.06 \pm 0.05$ & $35.58 \pm 0.12$ & $49.63 \pm 0.13$ & $65.85 \pm 0.18$ \\
\hline $6 B$ & $29.44 \pm 0.07$ & $44.79 \pm 0.36$ & $70.12 \pm 0.10$ & $32.62 \pm 0.07$ & $54.56 \pm 0.10$ & $72.14 \pm 0.45$ \\
\hline $7 B$ & $43.37 \pm 0.03$ & $60.12 \pm 0.16$ & $71.85 \pm 0.08$ & $42.83 \pm 0.05$ & $56.87 \pm 0.17$ & $76.16 \pm 0.11$ \\
\hline $8 B$ & $36.16 \pm 0.20$ & $45.13 \pm 0.11$ & $52.90 \pm 0.02$ & $49.73 \pm 0.77$ & $66.41 \pm 0.50$ & $104.36 \pm 0.09$ \\
\hline mean & $44.81 \pm 10.50$ & $52.06 \pm 4.94$ & $62.48 \pm 6.59$ & $41.60 \pm 6.15$ & $46.38 \pm 10.48$ & $63.11 \pm 20.22$ \\
\hline grand mean & & & & $53.12 \pm 10.52$ & $50.36 \pm 16.26$ & \\
\hline
\end{tabular}

${ }^{\star} \mathrm{SD}=$ standard deviation

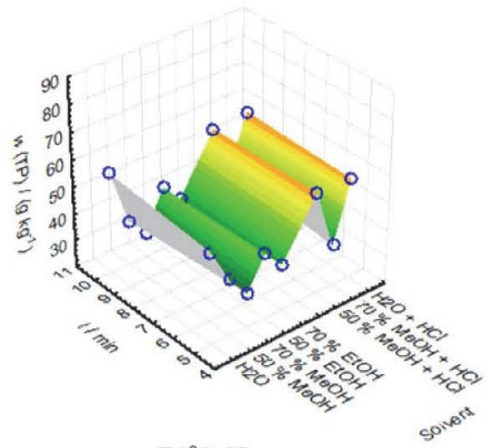

$T /{ }^{\circ} \mathrm{C}: 25$

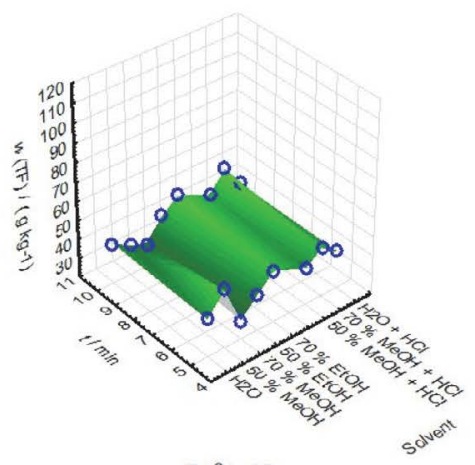

$T /{ }^{\circ} \mathrm{C}: 25$

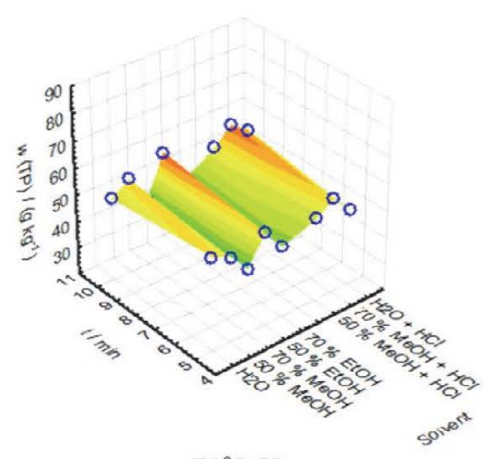

$T /{ }^{\circ} \mathrm{C}: 55$

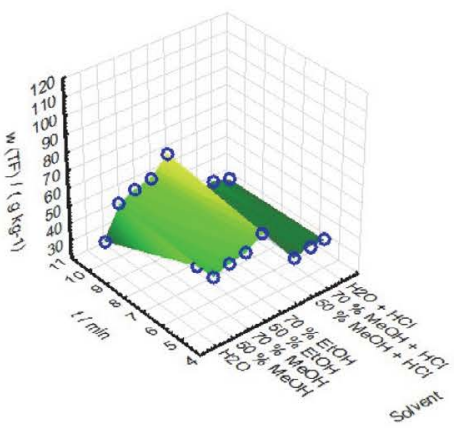

$T /{ }^{\circ} \mathrm{C}: 55$

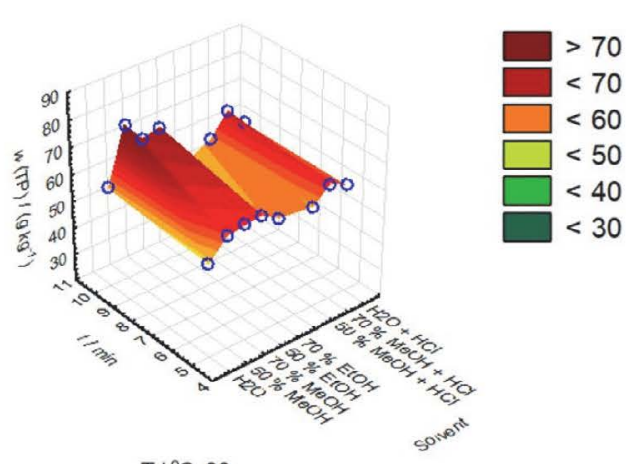

$T /{ }^{\circ} \mathrm{C}: 90$

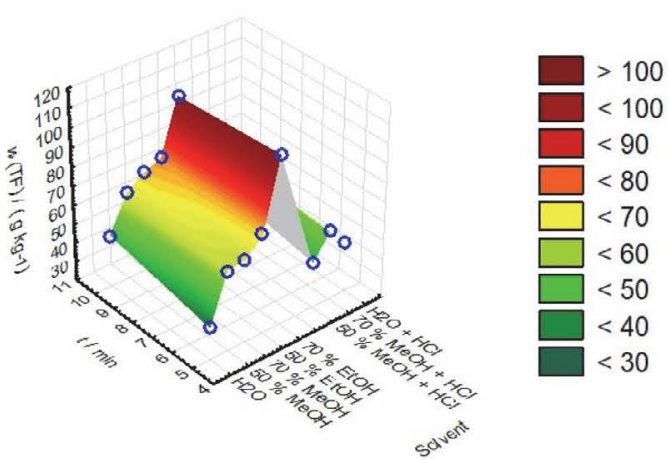

$T /{ }^{\circ} \mathrm{C}: 90$

Figure 1. 3D categorized plots of temperature $\left(25,55\right.$ and $\left.90^{\circ} \mathrm{C}\right)$, time ( 5 and $\left.10 \mathrm{~min}\right)$, and solvent interactions on contents of total phenols (TP) and total flavonoids (TF), extracted from tomato peel waste by MAE. 
hanced TF content, due to acceleration of solvent diffusion into the sample matrix. However, some values obtained for $\mathrm{TF}$ were greater than the corresponding (same temperature, time and solvent) TP values, particularly that obtained after extraction at $90{ }^{\circ} \mathrm{C}$, using water/organic solvent mixtures. This can be accounted by consideration that some of the phenolic compounds (isoflavone, antocyanin, cinnamic acid, flavanone, flavones, chalcone, flavonol and aurone), ${ }^{31}$ as well as other organic compounds presented in tomato cuticle ${ }^{32}$ were involved in complexation with $\mathrm{AlCl}_{3}$. Due to the fact that $\mathrm{AlCl}_{3}$ is unspecific reagent in its chelating power, we could suppose that in total sum of flavonoids were additionally included reactions with all of other mentioned compounds.

In contrast to effects of temperature, increase of extraction time from 5 to $10 \mathrm{~min}$ had no significant influence on TP $(p=0.333826)$ and TF $(p=0.519694)$ contents (Figure 1 and Figure S2, SI). Therefore, extraction time of 5 min is sufficient for a successful microwave-assisted extraction of phenols from tomato peel waste, and could be considered as optimal for further MAE extraction.

Considering solvents used for extractions, the data (Table 2 and Figure 1) revealed that higher proportion of water added to organic solvents provided better diffusion of phenols through tomato peel cuticle and consequently yielded higher amounts of TP. In that context, 50\% methanol $(\mathbf{5 A}-\mathbf{B})$ and ethanol $(\mathbf{7 A}-\mathbf{B})$ provided better extraction of TP, compared to $70 \%$ methanol $(6 \mathbf{A}-\mathbf{B})$ and ethanol (8A-B), with some exception $\left(90^{\circ} \mathrm{C}, 5 \mathrm{~min}, 5 \mathrm{~A}\right.$ and $\left.6 \mathrm{~A}\right)$. Although, slightly higher values were obtained using $50 \%$ ethanol than $50 \%$ methanol with somewhat lower values obtained at $90{ }^{\circ} \mathrm{C}(\mathbf{5 B}-7 \mathrm{~B})$, both solvents can be considered an adequate choice for further MAE, depending on applied temperatures.

Several researches ${ }^{33,34}$ already suggested that a binary solvent system, with lower volume fractions of organic solvents were efficient for extractions of phenols. Moreover, pure water, particularly at lower temperatures of extraction $\left(25\right.$ and $\left.55^{\circ} \mathrm{C}\right)$ acted as excellent solvent compared to organic solvent/water mixtures (Table 1 and Figure 1), depending on extraction time (5 min). Due to the fact that water has higher dielectric constant and can thus absorb more microwave energy (by ionic conduction and dipole rotation mechanisms) compared to less polar solvents, the result is higher extraction of phenols.

Pure water was used by El-Mahan et al. ${ }^{27}$ for extraction of polyphenols from Egyptian tomato waste by MAE. They reported values of $355.5,375.0$ and 377.5 $\mathrm{mg} / 100 \mathrm{~g}$ (TP) and 43.33, 46.66 and $49.89 \mathrm{mg} / 100 \mathrm{~g}$ (TF), for 30, 60 and 90 seconds of extraction, respectively.

Except water, $1 \%$ aqueous solution of $\mathrm{HCl}$ as polar solvent at lower extraction temperature $\left(25^{\circ} \mathrm{C}\right)$ also gave the high amounts of TP, regardless of the extraction time. However, addition of $\mathrm{HCl}$ to other solvents, i.e. 50 and $70 \%$ methanol, did not significantly $(p>0.05)$ influence on TP and TF amounts (Figure 1 and Figure S3, SI). Com- pared to $1 \%$ aqueous $\mathrm{HCl}$, organic solvents/water mixture, particularly at temperatures of 55 and $90{ }^{\circ} \mathrm{C}$ assured better extractions of flavonoids (Table 2 and Figure 1). Considering common un-polar structure of flavonoids, it was expected that organic solvents/water mixtures will be more appropriate solvents than 50 and $70 \%$ methanol with addition of $1 \%$ hydrochloric acids.

In summary, tomato peel waste obtained from the canning industry possessed remarkable amounts of TP and TF, compared to values reported by other authors. ${ }^{8,12-14,23,35}$ In reference to other extraction parameters, temperature had the greatest effect on extraction yields of phenols and flavonoids. However, their recovery was also associated with the appropriate choice of solvent and its combination with temperature of extraction. In that context, the temperature of $90{ }^{\circ} \mathrm{C}$ and $50 \%$ methanol with addition of $1 \% \mathrm{HCl}$, as well as temperature of $90{ }^{\circ} \mathrm{C}$ and $70 \%$ ethanol could be considered as optimal extraction conditions for phenols and flavonoids recovery from tomato peel waste, at time of $5 \mathrm{~min}$.

\section{2. Influence of Experimental Conditions on Individual Phenolic Compounds \\ Recovery}

The quantification of individual phenolic compounds, namely phenolic acids and their derivatives: $p$-coumaric acid $(\boldsymbol{p}$-CA $)$, cis- $p$-coumaric acid derivative (cis- $\boldsymbol{p}$-CA-der), $p$-coumaric acids hexoside (cis- $\boldsymbol{p}$-CA hexoside), chlorogenic acid (ChA), chlorogenic acid derivative (ChA-der), caffeic acid hexoside I (CA hexoside I), and caffeic acid hexoside II (CA hexoside II), and flavonols quercetin-pentosylrutinoside $(\mathbf{Q}$ pentosylrutinoside), quercetin-3-O-rutinoside (Q-3-O-rutinoside), kaempferol-pentosylrutinoside (K pentosylrutinoside), and kaempferol-3-O-rutinoside (K-3-O-rutinoside), in tomato peel extracts obtained after MAE was performed by HPLC-DAD analysis and are presented in Figure 2.

The studied compounds were identified in the majority of the extracts. Among them, CA hexoside I, CA hexoside II and ChA were not found in samples extracted by water, $1 \% \mathrm{HCl}$, and 50 and $70 \%$ ethanol, respectively. Furthermore, flavonols were not identified in samples extracted by water and $1 \% \mathrm{HCl}$. In addition, $\mathrm{Q}$ and $\mathrm{K}$ pentosylrutinoside, and Q-3-O-rutinoside was not found in 70\% ethanol, and 50\% methanol extracts, respectively.

Among phenolic acids and its derivatives (Figure 2), p-CA (3 to $111.5 \mathrm{mg} \mathrm{kg}^{-1}$ ) and ChA der (10.5 to $109 \mathrm{mg}$ $\mathrm{kg}^{-1}$ ) was predominant, compared to ChA (6 to $62 \mathrm{mg}$ $\mathrm{kg}^{-1}$ ) and cis- $p$-CA-der (1 to $47.5 \mathrm{mg} \mathrm{kg}^{-1}$ ). Regarding other derivatives, cis- $p$-CA hexoside, CA hexoside I and CA hexoside II were found in lower amounts, i.e. 0.5 to $29 \mathrm{mg}$ $\mathrm{kg}^{-1}, 1.5$ to $31 \mathrm{mg} \mathrm{kg}^{-1}$ and 9 to $25 \mathrm{mg} \mathrm{kg}^{-1}$, respectively.

Several papers ${ }^{8,10,15-17}$ reported the presence of phenolic acids (caffeic, chlorogenic, p-coumaric, ferulic, phloretic, sinapic, vannilic, syringic, gallic, and rosmarin- 


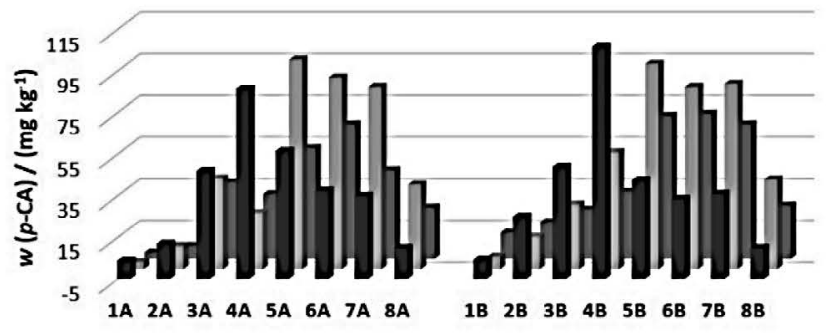

-25=55 90

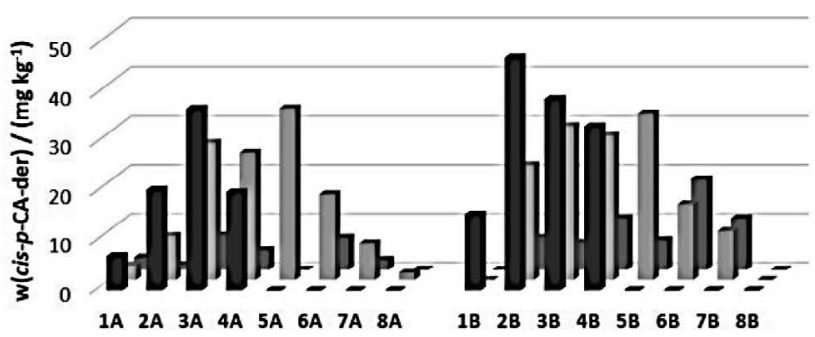

घ $25 \square \mathbf{5 5}=90$

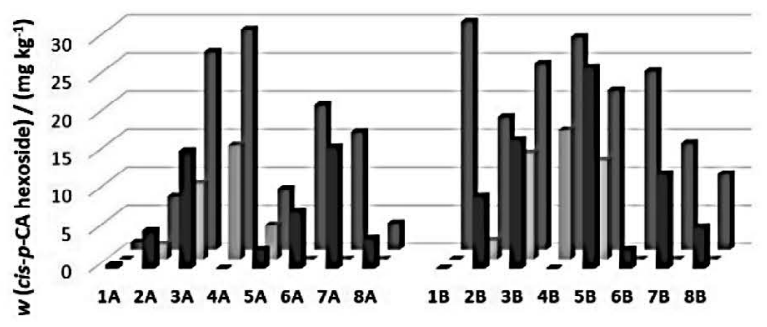

ロ25 $\mathbf{\square 5}=90$

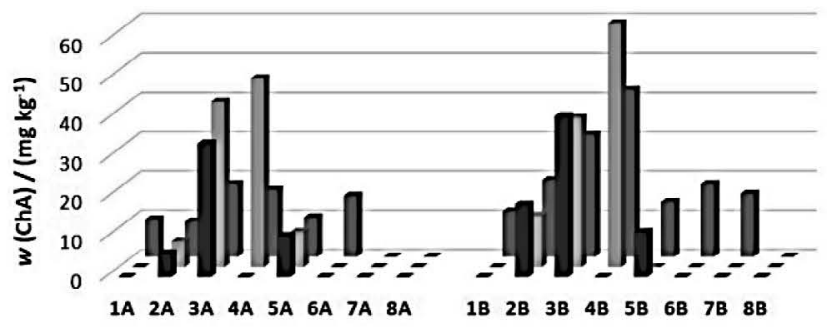

- $25=\mathbf{5 5}=90$

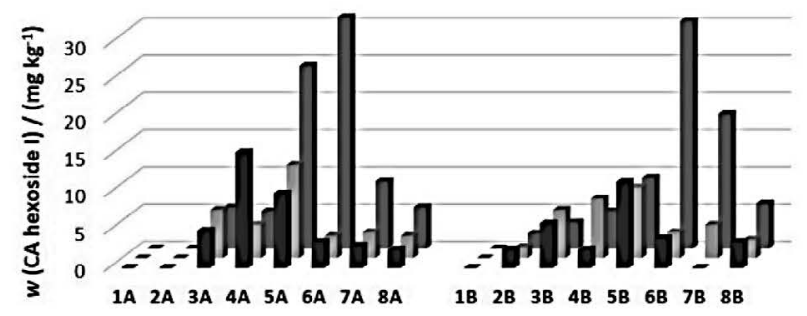

- $25=55=90$

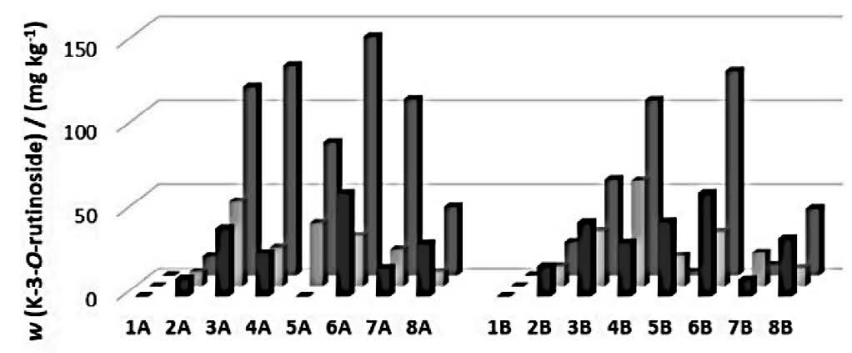

$\square 25=55 \square 90$

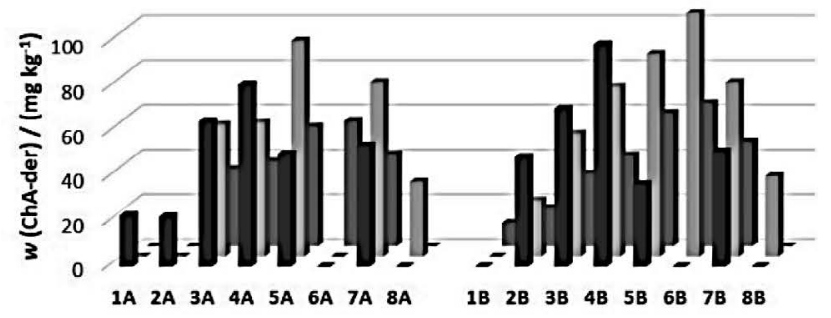

- $25=55=90$

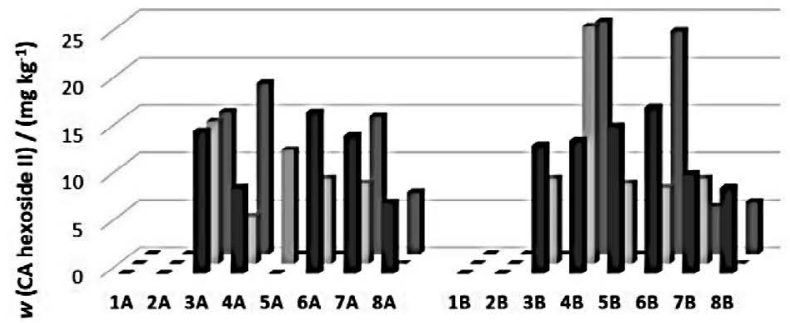

$\square 25=55 \square 90$

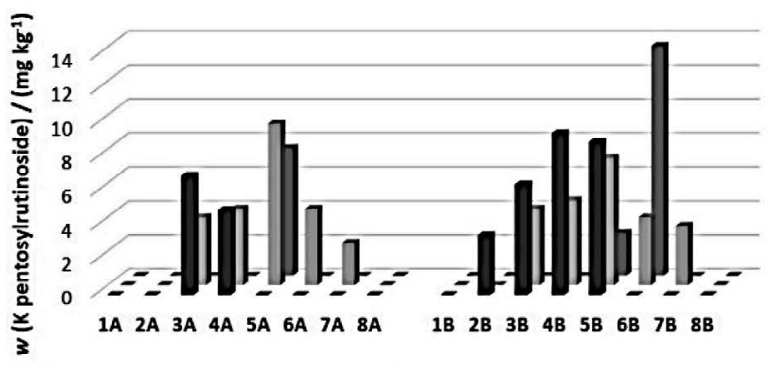

- $25=55=90$ 

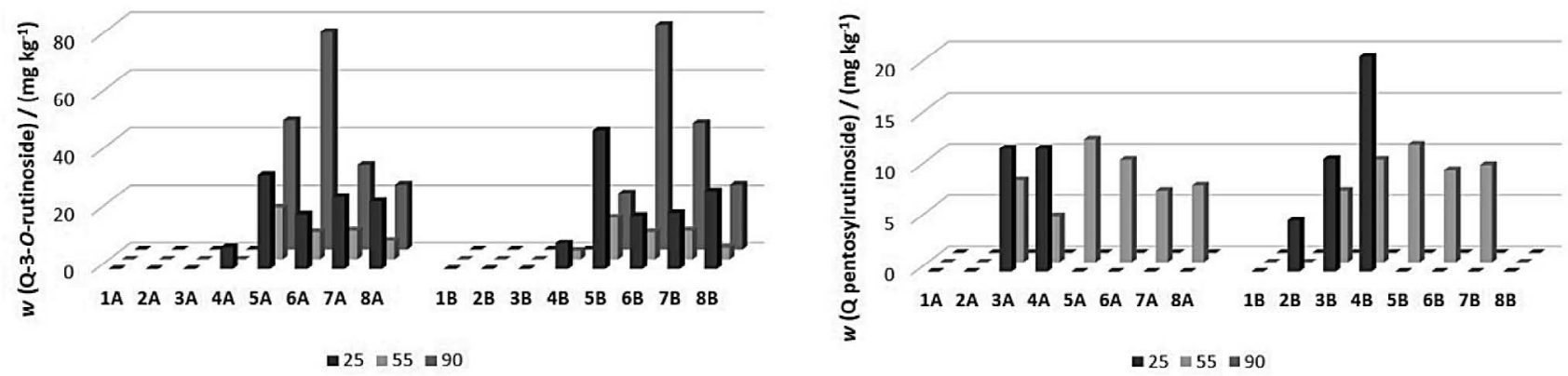

Figure 2. Content of individual phenolic compounds extracted from tomato peel waste by MAE, at temperature of 25,55 and $90{ }^{\circ} \mathrm{C}$, time of 5 min $(\mathbf{1 A - 8 A})$ and $10 \mathrm{~min}(\mathbf{1 B - 8 B})$, using water, $1 \% \mathrm{HCl}, 50$ and $70 \%$ methanol with and without addition of $1 \% \mathrm{HCl}$, and 50 and $70 \%$ ethanol.

ic) and their derivatives (chlorogenic, $p$-coumaric, ferulic-O-hexoside, and caffeic-O-hexoside), flavonoids (quercetin, rutin, chrysin, epicatechin, catechin, kaempferol, luteonin, and naringenin) and their derivatives, extracted from different tomato wastes. For instance, Kalogeropoulos et al. ${ }^{12}$ reported quantities of $p$-CA $\left(10.7 \mathrm{mg} \mathrm{kg}^{-1}, \mathrm{dw}\right)$ and ChA (51.7 $\mathrm{mg} \mathrm{kg}^{-1}, \mathrm{dw}$ ) lower than ours. Navarro-González et al. ${ }^{10}$ found $p$-CA and $p$-CA der in the range from 7.38 to $26.58 \mathrm{mg} \mathrm{kg}^{-1}$ (dw) and 33.00 to $141.10 \mathrm{mg}$ $\mathrm{kg}^{-1}$, respectively, depending on used extraction method (enzymatic treatment, maceration and sonication). ChA was also found in the works published by Lavelli and Torresani ${ }^{9}$ in quantities of 97 and $121 \mathrm{mg} \mathrm{kg}^{-1}(\mathrm{dw})$ for raw and heat-treated tomato by-products, and Aires et al. ${ }^{17}$ in the range from 17.3 to $43.7 \mathrm{mg} \mathrm{kg}^{-1}$ (dw), depending on the used extraction method and solvents.

Among flavonols (Figure 2) K-3-O-rutinoside was found in the highest amounts, 8.5 to $142.5 \mathrm{mg} \mathrm{kg}^{-1}$, depending on used solvent, temperature, and time. Q-3-O-rutinoside was also found in considerable amounts (3 to 78 $\mathrm{mg} \mathrm{kg}^{-1}$ ), compared to Q pentosylrutinoside ( 4.5 to $21 \mathrm{mg}$ $\mathrm{kg}^{-1}$ ) and $\mathrm{K}$ pentosylrutinoside (2.5 to $13 \mathrm{mg} \mathrm{kg}^{-1}$ ).

For comparison, the work of Kalogeropoulos et al. ${ }^{12}$ showed quantities of K-3-O-rutinoside of $5.5 \mathrm{mg} \mathrm{kg}^{-1}(\mathrm{dw})$ in tomato processing by-products. Aires et al. ${ }^{17}$ found 57.8 to $259.3 \mathrm{mg} \mathrm{kg}^{-1}$ (dw) of K-3-O-rutinoside and 15.0 to 45.1 $\mathrm{mg} \mathrm{kg}^{-1}(\mathrm{dw})$ of Q-3-O-rutinoside, depending on the used extraction method and solvents.

With the purpose to estimate the significance of MAE experimental parameters and interactions between them that provide the highest contents of individual phenolic compounds, the results of statistical analyses are described below.

The increase of extraction times from 5 to $10 \mathrm{~min}$ (Figure S4, SI) significantly influenced $(p=0.044719)$ the content of cis- $p$-CA hexoside. However, raise of time did not significantly affect the recovery of other isolated phenolic compounds. Therefore, the extraction time of $5 \mathrm{~min}$ is appropriate for their extraction, according to main advantage of MAE, i.e. applying shorter extraction time.

Regarding applied temperatures of extraction, the increases from 25 vs 55 to $90^{\circ} \mathrm{C}$ did not significantly influ- ence the $p$-CA, ChA, ChA der, K pentosylrutinoside, and CA hexoside II contents (Figure 3).

However, the raise of temperature significantly influenced the recovery of cis- $p$-CA der $\left(55\right.$ vs $90^{\circ} \mathrm{C}, p=$ $0.005986)$ and $\mathrm{Q}$ pentosylrutinoside $\left(25\right.$ vs $90{ }^{\circ} \mathrm{C}, p=$ 0.034721 and 55 vs $90{ }^{\circ} \mathrm{C}, p=0.000742$ ). In the case of these two compounds, the temperature of $90{ }^{\circ} \mathrm{C}$ should be avoided due to degradation effects. On the other hand, the temperature of $90{ }^{\circ} \mathrm{C}$ had a significant influence on the highest recovery of cis- $p$-CA hexoside $(p=0.000955$ for 25 vs $90^{\circ} \mathrm{C}$ and $p=0.000143$ for 55 vs $90^{\circ} \mathrm{C}$ ), CA hexoside I $\left(p=0.029699\right.$ for 25 vs $90^{\circ} \mathrm{C}$ and $\mathrm{p}=0.028620$ for 55 vs 90 ${ }^{\circ} \mathrm{C}$ ), and $\mathrm{K}-3-\mathrm{O}$-rutinoside ( $p=0.001415$ for 25 vs $90^{\circ} \mathrm{C}$ and $p=0.000466$ for 55 vs $90^{\circ} \mathrm{C}$ ) from tomato peel extracts.

Regarding solvents used for $p$-CA extraction from tomato peel (Figure 3), 50 and $70 \%$ methanol with and without addition of $1 \% \mathrm{HCl}$, as well as $50 \%$ ethanol showed significant $(p<0.05)$ influence on $p$-CA recovery, compared to water or $1 \% \mathrm{HCl}$ solution. Furthermore, significantly higher $(p<0.05)$ values were also obtained using 50 and $70 \%$ methanol compared to 50 and $70 \%$ ethanol.

In the case of cis-p-CA der, several solvents, such as $1 \% \mathrm{HCl}, 50$ and $70 \%$ methanol with and without addition of $\mathrm{HCl}$ can be considered as a good choice for cis- $p$-CAder extraction by MAE. Due to the fact that temperature of $90{ }^{\circ} \mathrm{C}$ had a significant effect on degradation of cis- $p$-CA der, the temperature of $25^{\circ} \mathrm{C}$ in combinations with $1 \%$ $\mathrm{HCl}$ and 50 and $70 \%$ methanol with addition of $1 \% \mathrm{HCl}$ could be recommended for its extraction, particularly for $10 \mathrm{~min}$. In addition, high contents of cis-p-CA-der, i.e. 35 and $34 \mathrm{mg} \mathrm{kg}^{-1}$ for 5 and $10 \mathrm{~min}$ of extraction, using 50\% methanol, at $55^{\circ} \mathrm{C}$ revealed that this combination could be also applied for further successful extraction of this compound by MAE.

High contents of cis- $p$-CA hexoside (Figures 2 and 3) were obtained at $90^{\circ} \mathrm{C}$, using 50 and $70 \%$ methanol with addition of $1 \% \mathrm{HCl}$, which confirmed these solvents efficiency not only for $p$-CA and cis- $p$-CA der extractions, but also for cis- $p$-CA hexoside. Mentioned solvents can be also recommended for extractions of $\mathrm{ChA}$ and its derivatives, due to significant $(p<0.05)$ influence on their quantities. 

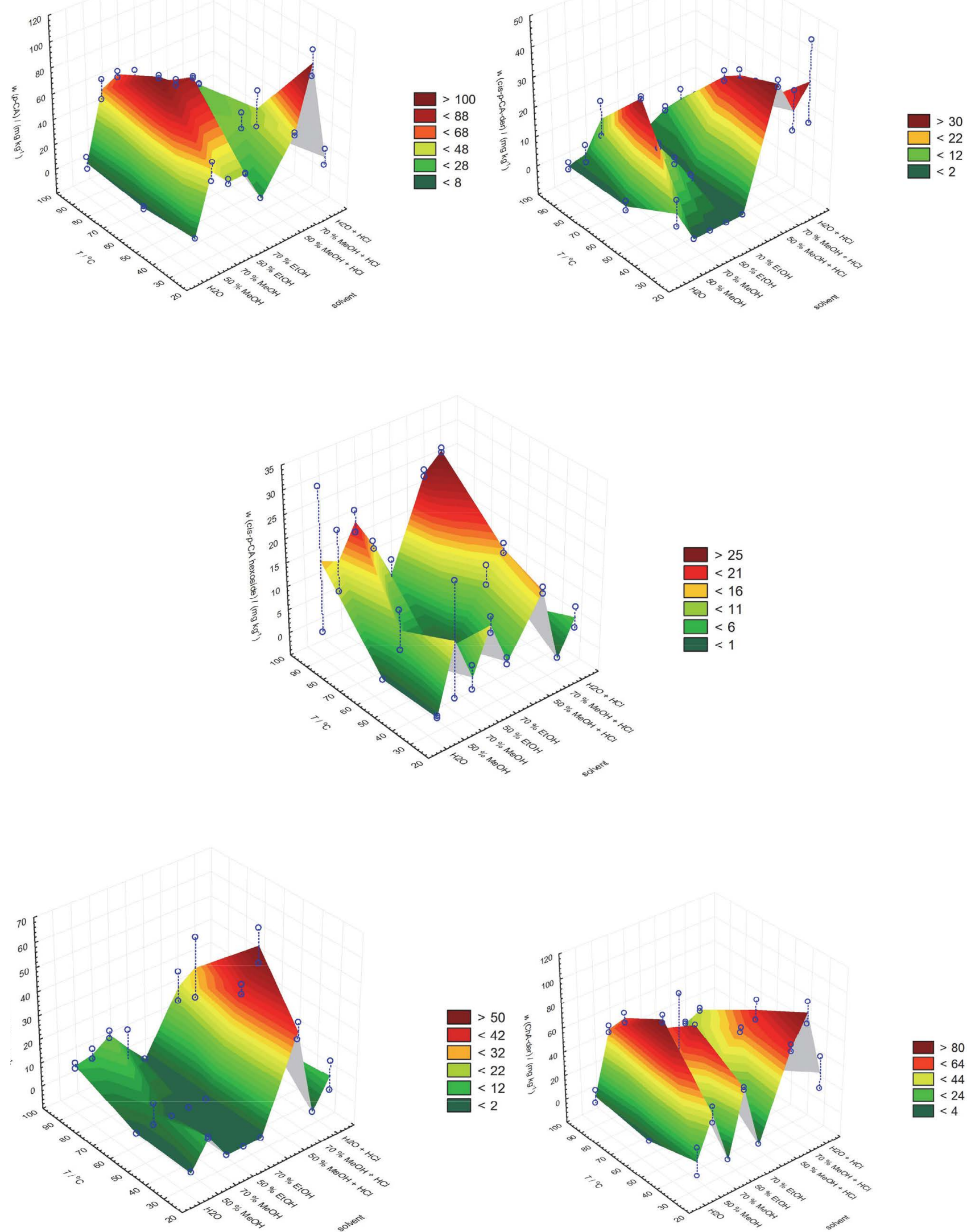

Bakić et al.: Effect of Microwave-Assisted Extraction ... 

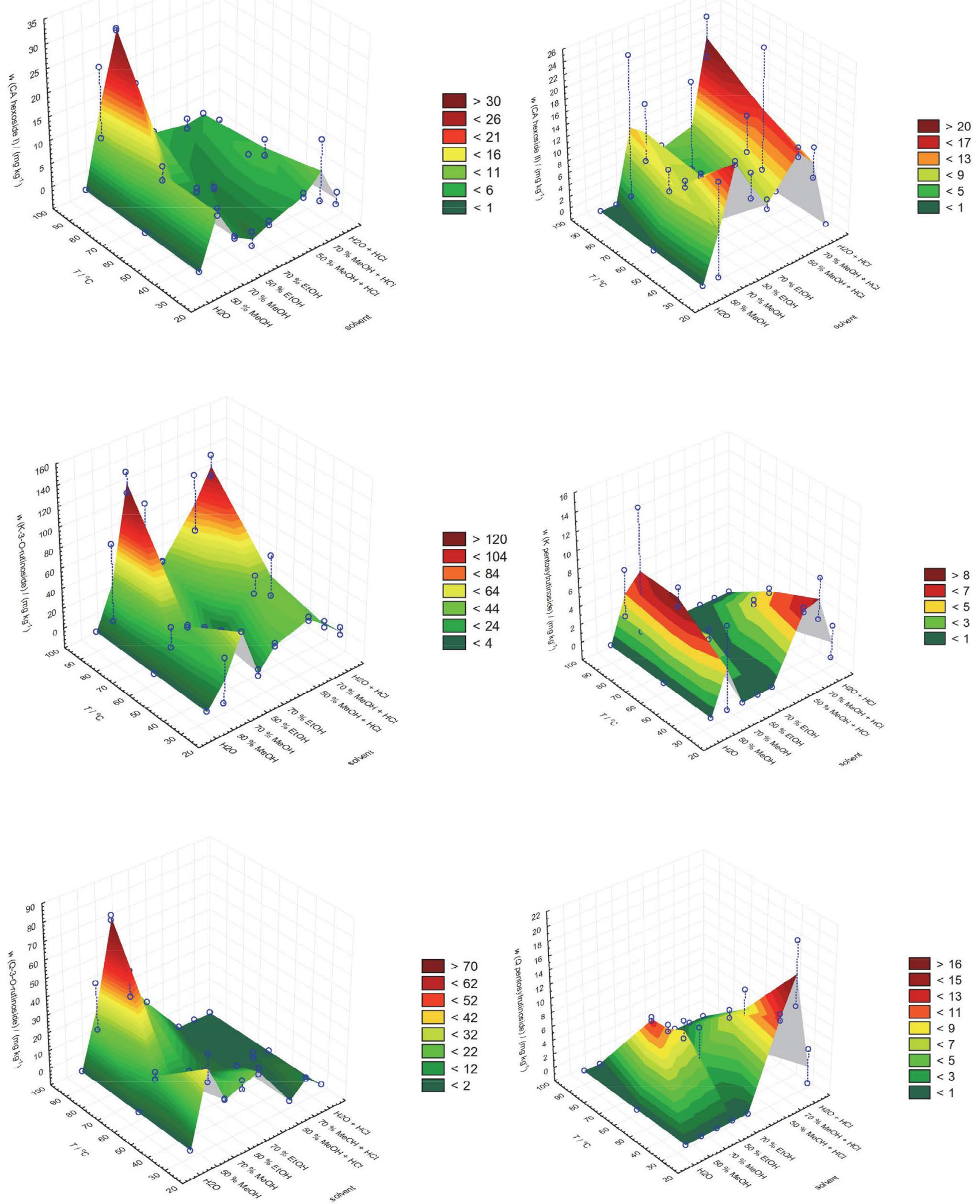

Figure 3. Influence of temperature $\left(25,55\right.$ and $\left.90^{\circ} \mathrm{C}\right)$ and solvent on contents of individual phenolic compounds extracted from tomato peel waste by MAE 
For instance, using $50 \%$ methanol with addition of $1 \%$ $\mathrm{HCl}$ (3A-B) significant differences of ChA were observed vs water $(p=0.000486), 1 \% \mathrm{HCl}(p=0.020184), 50 \%$ methanol $(p=0.005655), 70 \%$ methanol $(p=0.001195)$, $50 \%$ ethanol $(p=0.000364)$ and $70 \%$ ethanol $(p=$ $0.020184)$. By $70 \%$ ethanol with addition of $1 \% \mathrm{HCl}(\mathbf{4 A}-$ B), the obtained $p$-values were also significant vs: water ( $p$ $=0.006096), 70 \%$ methanol $(p=0.015760), 50 \%$ ethanol $(p$ $=0.004196)$ and $70 \%$ ethanol $(p=0.001284)$. Furthermore, 50 and $70 \%$ methanol or ethanol without addition of $1 \% \mathrm{HCl}$ can also be used for ChA extraction, depending on temperature and extraction time.

In the case of CA hexoside I and II, 50 and $70 \%$ methanol with and without addition of $1 \% \mathrm{HCl}$ showed significant influence on their contents, compared to water or $1 \% \mathrm{HCl}$.

Regarding flavonols, the extraction of Q-3-O-rutinoside was significantly influenced by $50 \%(p=0.004893)$ and $70 \%$ methanol $(p=0.000641)$. The highest amounts were obtained by $70 \%$ methanol, i.e. 75.5 and $78 \mathrm{mg} \mathrm{kg}^{-1}$, for 5 and $10 \mathrm{~min}$ of extraction.

The recovery of K-3-O-rutinoside was significantly influenced by $70 \%$ methanol ( $p=0.000283$ ), 50 and $70 \%$ methanol with addition of $\mathrm{HCl}(p=0.007673$ and $p=$ 0.002455), compared to other used solvents. High extraction yield of this compound was obtained at temperature of $90{ }^{\circ} \mathrm{C}$ for $5 \mathrm{~min}$, using $70 \%$ methanol $(142.5 \mathrm{mg}$ $\mathrm{kg}^{-1}$ ), followed by $70 \%$ and $50 \%$ methanol with addition of $1 \% \mathrm{HCl}$, which gave values of 125 and $112.5 \mathrm{mg} \mathrm{kg}^{-1}$, respectively.

Although found in minor amounts (Figures 2 and 3), extractions of $\mathrm{Q}$ pentosylrutinoside and $\mathrm{K}$ pentosylrutinoside were affected by application of organic solvents, regardless of addition of $1 \% \mathrm{HCl}$.

To summarize, the HPLC-DAD analyses revealed that tomato peel waste presents an important source for exploitation of phenolic compounds. However, their contents depend on extraction conditions, with emphasis on interaction between the chosen temperature and solvent. The addition of $1 \% \mathrm{HCl}$ to 50 or $70 \%$ methanol assured good recovery of majority of phenolic acids and their derivatives. However, $50 \%$ and particularly $70 \%$ methanol provided better recovery of some flavonols, such as $\mathrm{K}-3-\mathrm{O}$-rutinoside. In addition, particular care should be taken regarding the temperature applied during MAE, since an increase in temperature can have a profound influence on degradation of cis- $p$-CA-der and Q pentosylrutinoside, as well as enhancement of amounts of cis- $p$-CA hexoside, CA hexoside I and $\mathrm{K}-3-\mathrm{O}$-rutinoside.

Therefore, taking into account that extraction time had no significant influence on extraction of majority of phenolic compounds, we propose the extraction time of 5 min in combination with the follow solvent and temperature as optimal, i.e. that which exhibited the highest recovery of phenolic compound: $i$ ) $50 \%$ methanol with addition of $1 \% \mathrm{HCl}$ and $25{ }^{\circ} \mathrm{C}$ for cis-p-CA der, ii) $70 \%$ methanol with addition of $1 \% \mathrm{HCl}$ and $55^{\circ} \mathrm{C}$ for $\mathrm{ChA}$, and $90^{\circ} \mathrm{C}$ for cis- $p$-CA hexoside and CA hexoside II, respectively, iii) $50 \%$ methanol and $90^{\circ} \mathrm{C}$ for $p$-CA, and $55^{\circ} \mathrm{C}$ for $\mathrm{ChA}$ der, $\mathrm{Q}$ pentosylrutinoside and $\mathrm{K}$ pentosylrutinoside, respectively and iv) $70 \%$ methanol and $90{ }^{\circ} \mathrm{C}$ for CA hexoside I, Q-3-O-rutinoside and K-3-O-rutinoside.

\section{Conclusion}

The present study showed that tomato peel waste from the canning industry could be utilized as a sustainable, low cost source for polyphenols production.

Results revealed that polyphenols were isolated in remarkable amounts with minimal expenditure of time (5 min), applying MAE as an innovative and eco-friendly technique. Among evaluated extraction parameter, temperatures and solvents have a considerable influence on total phenols, total flavonoids, and individual phenolic compounds yields. Various combinations of these parameters result with isolation of different amounts of individual phenolic compounds.

Therefore, additional MAE extractions of tomato peel waste should be performed combining temperature and solvent type adequate for isolation of one or more target compounds with similar structures and properties.

\section{Acknowledgements}

This work was supported by the Croatian Ministry of Science, Education, and Sports, No. 058-0580000-3071. The authors are grateful to Giovanni Paolo Buoninconti from Benincasa S.r.l., Angri (SA) canning industry for providing the tomato peel waste.

\section{Reference}

1. A. Zuorro, R. Lavecchia, F. Medici and L. Piga, Chem. Eng. Trans. 2014, 38, 355-360.

2. K. Valta, P. Damala, V. Panaretou, E. Orli, K. Moustakas and M. Loizidou, Waste Biomass Valor. 2017, 8, 1629-1648.

DOI:10.1007/s12649-016-9672-4

3. V. Nour, T. D. Panaite, M. Ropota, R. Turcu, I. Trandafir and A. R. Corbu. Cyta - J. Food. 2018, 16, 222-229.

DOI:10.1080/19476337.2017.1383514

4. N. Balasundram, K. Sundram and S. Samman, Food Chem. 2006, 99, 191-203. DOI:10.1016/j.foodchem.2005.07.042

5. I. Ignat, I. Volf and V. I. A Popa, Food Chem. 2011, 126, 18211835. DOI:10.1016/j.foodchem.2010.12.026

6. C. Fritsch, A. Staebler, A. Happel, M. A. Cubero Márquez, I. Aguiló-Aguayo, M. Abadias, M. Gallur, I. Maria Cigognini, A. Montanari, M. J. López, F. Suárez-Estrella, N. Brunton, E. Luengo, L. Sisti, M. Ferri and G. Belotti, Sustainability 2017, 9, 1-46. DOI:10.3390/su9081492 
7. N. Ahmad, Y. Zuo, X. Lu, F. Anwar and S. Hameed, Food Chem. 2016, 190, 80-89. DOI:10.1016/j.foodchem.2015.05.077

8. W. Peschel, F. Sánchez-Rabaneda, W. Diekmann, A. Plescher, I. Gartzía, D. Jiménez, R. Lamuela-Raventós, S. Buxaderas and C. Codina, Food Chem. 2006, 97, 137-150.

DOI:10.1016/j.foodchem.2005.03.033

9. V. Lavelli and M. C. Torresani, Food Chem. 2011, 125, 529535. DOI:10.1016/j.foodchem.2010.09.044

10. I. Navarro-González, V. García-Valverde, J. García-Alonso and M. J. Periago, Food Res. Int. 2011, 44, 1528-1535.

DOI:10.1016/j.foodres.2011.04.005

11. V. Lavelli and A. Scarafoni, J. Food Eng. 2012, 110, 225-231. DOI:10.1016/j.jfoodeng.2011.05.025

12. N. Kalogeropoulos, A. Chiou, V. Pyriochou, A. Peristeraki and V. T. Karathanos, LWT - Food Sci. Technol. 2012, 49, 213-216.

13. A. Vallverdú-Queralt, A. Medina-Remón, I. Casals-Ribes, C. Andres-Lacueva, A. L. Waterhouse and R. M. Lamuela-Raventos, LWT - Food Sci. Technol. 2012, 47, 154-160.

14. A. Sarkar and P. Kaul, J. Food Process Eng. 2014, 37, 299-307. DOI:10.1111/jfpe.12086

15. E. Elbadrawy and A. Sello, Arab. J. Chem. 2016, 9, S1010-S1018. DOI:10.1016/j.arabjc.2011.11.011

16. S. Savatović, G. Ćetković, J. Čanadanović-Brunet and S. Djilas, Acta Period. Technol. 2010, 41, 187-194.

DOI:10.2298/APT1041187S

17. A. Aires, R. Carvalho and M. J. Saavedra, Int. J. Food Sci. Technol. 2017, 52, 98-107. DOI:10.1111/ijfs. 13256

18. C. D. Stalikas, J. Sep. Sci. 2007, 30, 3268-3295. DOI:10.1002/jssc.200700261

19. H. Wijngaard, M. B. Hossain, D. K. Rai and N. Brunton, Food Res. Int. 2012, 46, 505-513.

DOI:10.1016/j.foodres.2011.09.027

20. P. Garcia-Salas, A. Morales-Soto, A. Segura-Carretero and A. Fernández-Gutiérrez, Molecules. 2010, 15, 8813-8826.

DOI:10.3390/molecules15128813

21. A. Khoddami, M. Wilkes and T. Roberts, Molecules. 2013, 18, 2328-2375. DOI:10.3390/molecules 18022328
22. I. S. M. Azmir, M. M. Zaidul, K. M. Rahman, A. Sharif, F. Mohamed, M. H. A. Sahena, Jahurul, K. Ghafoor, N. A. N. Norulaini and A. K. M. Omar, J. Food Eng. 2013, 117, 426-436.

DOI:10.1016/j.jfoodeng.2013.01.014

23. J. R. K. Toor and G. P. Savage, Food Res. Int. 2005, 38, 487-494. DOI:10.1016/j.foodres.2004.10.016

24. M. Viuda-Martos, E. Sanchez-Zapata, E. Sayas-Barberá, E. Sendra, J. A. Pérez-Álvarez and J. Fernández-López. J. Crit. Rev. Food Sci. Nutr. 2014, 54, 1032-1049.

DOI:10.1080/10408398.2011.623799

25. V. Nour, M. E. Ionica and I. Trandafir, J. Food Sci. Technol. 2015, 52, 8260-8267. DOI:10.1007/s13197-015-1934-9

26. U. Ahmad, Z. Mushtaq, R. S. Ahmad and N. Asghar, The J. Anim. Plant Sci. 2017, 27, 2045-2055.

27. M. H. El-Malah, M. M. M. Hassanein, M. H. Areif and E. F. Al-Amrousi, Am. J. Food Technol. 2015, 10, 14-25. DOI:10.3923/ajft.2015.14.25

28. G. A. Spanos and R. E. Wrolstad, J. Agric. Food Chem. 1990, 38, 1565-1571. DOI:10.1021/jf00097a030

29. J. Zhishen, T. Mengcheng and W. Jianming, Food Chem. 1999, 64, 555-559. DOI:10.1016/S0308-8146(98)00102-2

30. L. Barros, M. Dueñas, A. M. Carvalho, I. C. F. R. Ferreira and C. Santos-Buelga, Food Chem. Toxicol. 2012, 50, 1576-1582. DOI:10.1016/j.fct.2012.02.004

31. J. B. Harborne, in J. B. Pridhan (Ed.): Methods in Polyphenol Chemistry, Elsevier, Oxford, England, 1964, pp. 13-36. DOI:10.1016/B978-0-08-010887-2.50006-2

32. K. H. Caffall and D. Mohnen, Carbohydr. Res. 2009, 344, 1879-1900. DOI:10.1016/j.carres.2009.05.021

33. M. Dent, V. Dragović-Uzelac, M. Penić, M. Brnčić, T. Bosiljkov and B. Levaj, Food Technol. Biotechnol. 2013, 51, 84-91.

34. P. Putnik, D. B. Kovačević, M. Penić, M. Fegeš and V. Dragović-Uzelac, Food Anal. Methods. 2016, 9, 2385-2394. DOI:10.1007/s12161-016-0428-3

35. S. Gharbi, G. Renda, L. La Barbera, M. Amri, C. M. Messina and A. Santulli, Nat. Prod. Res. 2017, 31, 626-631.

DOI:10.1080/14786419.2016.1209671

\section{Povzetek}

$\mathrm{V}$ delu je preučena uporaba ekstrakcije z mikrovalovi (ang. MAE) kot inovativna tehnika za izolacijo polifenolov iz odpadnih olupkov paradižnika. Ovrednotili smo vpliv topila, temperature $\left(25,55\right.$ in $\left.90^{\circ} \mathrm{C}\right)$ in časa $(5$ in 10 min $)$ glede vsebnosti celotnih fenolov (TP), celotnih flavonoidov (TF) in fenolnih spojin. Odpadni olupki paradižnikov vsebujejo visoke količine kaemferol-3-O-rutinozida ( 8.5 do $\left.142.5 \mathrm{mg} \mathrm{kg}^{-1}\right)$, $p$-kumarinske kisline (3 do $\left.111.5 \mathrm{mg} \mathrm{kg}^{-1}\right)$ in derivate klorogene kisline (10.5 do $\left.109 \mathrm{mg} \mathrm{kg}^{-1}\right)$. Izkazalo se je, da čas ekstrakcije nima znatnega vpliva $(p>0.05)$ na izkoristek TP, TF in fenolnih spojin (z izjemo heksazida cis-p-kumarinske kisline). Po drugi strani pa se je izkazalo, da je izkoristek polifenolov odvisen od temperature in izbranega topila. Upoštevaje znatno zanimanje uporabnikov za uživanje naravnih snovi $\mathrm{z}$ antioksidativnimi lastnostmi, predstavljena raziskava kaže, da lahko ostanke paradižnikovih lupin uporabimo kot trajnostni vir polifenolov $\mathrm{z}$ uporabe MAE. 